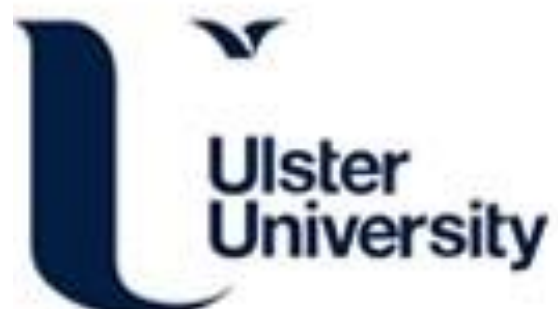

The heritage tourist: an understanding of the visitor experience at heritage attractions

Kempiak, J., Hollywood, L., Bolan, P., \& McMahon-Beattie, U. (2017). The heritage tourist: an understanding of the visitor experience at heritage attractions. International Journal of Heritage Studies, 23(4), 375-392.

https://doi.org/10.1080/13527258.2016.1277776

Link to publication record in Ulster University Research Portal

\section{Published in:}

International Journal of Heritage Studies

Publication Status:

Published online: 26/01/2017

DOI:

10.1080/13527258.2016.1277776

\section{Document Version}

Author Accepted version

\section{General rights}

Copyright for the publications made accessible via Ulster University's Research Portal is retained by the author(s) and / or other copyright owners and it is a condition of accessing these publications that users recognise and abide by the legal requirements associated with these rights.

\section{Take down policy}

The Research Portal is Ulster University's institutional repository that provides access to Ulster's research outputs. Every effort has been made to ensure that content in the Research Portal does not infringe any person's rights, or applicable UK laws. If you discover content in the Research Portal that you believe breaches copyright or violates any law, please contact pure-support@ulster.ac.uk. 


\section{PROOF COVER SHEET}

Author(s): Joanna Kempiak

Article title: The heritage tourist: an understanding of the visitor experience at heritage attractions

Article no: RJHS 1277776

Enclosures: 1) Query sheet

2) Article proofs

Dear Author,

Please find attached the proofs for your article.

1. Please check these proofs carefully. It is the responsibility of the corresponding author to check these and approve or amend them. A second proof is not normally provided. Taylor \& Francis cannot be held responsible for uncorrected errors, even if introduced during the production process. Once your corrections have been added to the article, it will be considered ready for publication

Please limit changes at this stage to the correction of errors. You should not make trivial changes, improve prose style, add new material, or delete existing material at this stage. You may be charged if your corrections are excessive (we would not expect corrections to exceed 30 changes).

For detailed guidance on how to check your proofs, please paste this address into a new browser window: $\mathrm{http}$ //journalauthors.tandf.co.uk/production/checkingproofs.asp

Your PDF proof file has been enabled so that you can comment on the proof directly using Adobe Acrobat. If you wish to do this, please save the file to your hard disk first. For further information on marking corrections using Acrobat, please paste this address into a new browser window:http://journalauthors.tandf.co.uk/production/acrobat.asp

2. Please review the table of contributors below and confirm that the first and last names are structured correctly and that the authors are listed in the correct order of contribution. This check is to ensure that your names will appear correctly online and when the article is indexed.

\begin{tabular}{|c|c|c|c|c|}
\hline Sequence & Prefix & Given name(s) & Surname & Suffix \\
\hline 1 & & Joanna & Kempiak & \\
2 & & Lynsey & Hollywood & \\
3 & & Peter & Bolan & \\
4 & & Una & McMahon-Beattie & \\
& & & & \\
\hline
\end{tabular}


Queries are marked in the margins of the proofs, and you can also click the hyperlinks below.

Content changes made during copy-editing are shown as tracked changes. Inserted text is in red font and revisions have a blue indicator $\curlywedge$. Changes can also be viewed using the list comments function. To correct the proofs, you should insert or delete text following the instructions below, but do not add comments to the existing tracked changes.

\section{AUTHOR QUERIES}

\section{General points:}

1. Permissions: You have warranted that you have secured the necessary written permission from the appropriate copyright owner for the reproduction of any text, illustration, or other material in your article. For further guidance on this topic please see: http://journalauthors.tandf.co.uk/copyright/usingThirdPartyMaterial.asp

2. Third-party material: If there is material in your article that is owned by a third party, please check that the necessary details of the copyright/rights owner are shown correctly.

3. Affiliation: The corresponding author is responsible for ensuring that address and email details are correct for all the co-authors. Affiliations given in the article should be the affiliation at the time the research was conducted. For further guidance on this topic please see: http://journalauthors.tandf.co.uk/preparation/ writing.asp.

4. Funding: Was your research for this article funded by a funding agency? If so, please insert 'This work was supported by <insert the name of the funding agency in full>', followed by the grant number in square brackets '[grant number $\mathrm{xxxx}]$ '.

5. Supplemental data and underlying research materials: Do you wish to include the location of the underlying research materials (e.g. data, samples or models) for your article? If so, please insert this sentence before the reference section: 'The underlying research materials for this article can be accessed at $<$ full link $>$ / description of location [author to complete]'. If your article includes supplemental data, the link will also be provided in this paragraph. See $<$ http://journalauthors.tandf.co.uk/preparation/multimedia.asp $>$ for further explanation of supplemental data and underlying research materials.

6. The CrossRef database (www.crossref.org/) has been used to validate the references. Changes resulting from mismatches are tracked in red font.

\begin{tabular}{|c|l|}
\hline AQ1 & $\begin{array}{l}\text { The keywords has been imported from data supplied with the original manuscript. Please } \\
\text { revise if incorrect. }\end{array}$ \\
\hline AQ2 & $\begin{array}{l}\text { The reference "Timothy 1997" is cited in the text but is not listed in the references list. } \\
\text { Please either delete in-text citation or provide full reference details following journal style. }\end{array}$ \\
\hline AQ3 & Please check that the heading levels have been correctly formatted throughout. \\
\hline AQ4 & $\begin{array}{l}\text { The reference "Prentice 1993" is cited in the text but is not listed in the references list. Please } \\
\text { either delete in-text citation or provide full reference details following journal style. }\end{array}$ \\
\hline AQ5 & $\begin{array}{l}\text { The reference "Ho et al. 2004" is cited in the text but is not listed in the references list. Please } \\
\text { either delete in-text citation or provide full reference details following journal style. }\end{array}$ \\
\hline
\end{tabular}




\begin{tabular}{|c|c|}
\hline AQ6 & $\begin{array}{l}\text { The spelling of Name for "Cunnel and Prentice } 2000 \text { " has been changed to "Cunnell and } \\
\text { Prentice } 2000 " \text { to match the entry in the references list. Please confirm that this is correct } \\
\text { and provide revisions if needed. }\end{array}$ \\
\hline AQ7 & $\begin{array}{l}\text { The reference "Patterson and Bitgood 1988" is cited in the text but is not listed in the } \\
\text { references list. Please either delete in-text citation or provide full reference details following } \\
\text { journal style. }\end{array}$ \\
\hline AQ8 & $\begin{array}{l}\text { The Year for "Rashid } 2007 \text { " has been changed to "Rashid } 2013 \text { " to match the entry in the } \\
\text { references list. Please confirm this is correct and provide revisions if needed. }\end{array}$ \\
\hline AQ9 & $\begin{array}{l}\text { The reference "Northern Ireland Visitor Attraction Survey } 2013 \text { " is cited in the text but is } \\
\text { not listed in the references list. Please either delete in-text citation or provide full reference } \\
\text { details following journal style. }\end{array}$ \\
\hline AQ10 & $\begin{array}{l}\text { The reference "Comrey and Lee 1992" is cited in the text but is not listed in the references } \\
\text { list. Please either delete in-text citation or provide full reference details following journal } \\
\text { style. }\end{array}$ \\
\hline AQ11 & $\begin{array}{l}\text { Please provide the Notes on contributors (regarding current academic position and research } \\
\text { interests). }\end{array}$ \\
\hline AQ12 & The disclosure statement has been inserted. Please correct if this is inaccurate. \\
\hline AQ13 & $\begin{array}{l}\text { The CrossRef database (www.crossref.org/) has been used to validate the references. } \\
\text { Mismatches between the original manuscript and CrossRef are tracked in red font. Please } \\
\text { provide a revision if the change is incorrect. Do not comment on correct changes. }\end{array}$ \\
\hline AQ14 & $\begin{array}{l}\text { The reference "Check and Schutt 2012" is listed in the references list but is not cited in the } \\
\text { text. Please either cite the reference or remove it from the references list. }\end{array}$ \\
\hline AQ15 & $\begin{array}{l}\text { Please provide missing last page number for the "Harrison and Shaw 2004" references list } \\
\text { entry. }\end{array}$ \\
\hline AQ16 & $\begin{array}{l}\text { The reference "Ho and McKercher 2004" is listed in the references list but is not cited in the } \\
\text { text. Please either cite the reference or remove it from the references list. }\end{array}$ \\
\hline AQ17 & $\begin{array}{l}\text { Please provide missing volume number and page numbers for the "Leask et al. 2013a" } \\
\text { references list entry. }\end{array}$ \\
\hline AQ18 & Please provide missing city and publisher for the "Mintel 2010 " references list entry. \\
\hline AQ19 & Please provide missing city for the "Neuhofer et al. 2013" references list entry. \\
\hline AQ20 & Please provide missing city for the "OECD 2009" references list entry. \\
\hline AQ21 & Please provide missing city for the "OECD 2012" references list entry. \\
\hline AQ22 & $\begin{array}{l}\text { The reference "Poria et al. 2001" is listed in the references list but is not cited in the text. } \\
\text { Please either cite the reference or remove it from the references list. }\end{array}$ \\
\hline AQ23 & Please provide missing city for the "Richards 2001a" references list entry. \\
\hline AQ24 & Please provide missing city for the "UNWTO 2010" references list entry. \\
\hline AQ25 & Please provide missing volume number for the "Wu and Wall 2016" references list entry. \\
\hline
\end{tabular}




\section{How to make corrections to your proofs using Adobe Acrobat/Reader}

Taylor \& Francis offers you a choice of options to help you make corrections to your proofs. Your PDF proof file has been enabled so that you can mark up the proof directly using Adobe Acrobat/Reader. This is the simplest and best way for you to ensure that your corrections will be incorporated. If you wish to do this, please follow these instructions:

1. Save the file to your hard disk.

2. Check which version of Adobe Acrobat/Reader you have on your computer. You can do this by clicking on the "Help" tab, and then "About".

If Adobe Reader is not installed, you can get the latest version free from http://get.adobe.com/reader/.

3. If you have Adobe Acrobat/Reader 10 or a later version, click on the "Comment" link at the right-hand side to view the Comments pane.

4. You can then select any text and mark it up for deletion or replacement, or insert new text as needed. Please note that these will clearly be displayed in the Comments pane and secondary annotation is not needed to draw attention to your corrections. If you need to include new sections of text, it is also possible to add a comment to the proofs. To do this, use the Sticky Note tool in the task bar. Please also see our FAQs here: http://journalauthors.tandf.co.uk/ production/index.asp.

5. Make sure that you save the file when you close the document before uploading it to CATS using the "Upload File" button on the online correction form. If you have more than one file, please zip them together and then upload the zip file.

If you prefer, you can make your corrections using the CATS online correction form.

\section{Troubleshooting}

Acrobat help:http://helpx.adobe.com/acrobat.html

Reader help:http://helpx.adobe.com/reader.html

Please note that full user guides for earlier versions of these programs are available from the Adobe Help pages by clicking on the link "Previous versions" under the "Help and tutorials" heading from the relevant link above. Commenting functionality is available from Adobe Reader 8.0 onwards and from Adobe Acrobat 7.0 onwards.

Firefox users: Firefox's inbuilt PDF Viewer is set to the default; please see the following for instructions on how to use this and download the PDF to your hard drive: http://support.mozilla.org/en-US/kb/viewpdf-files-firefox-without-downloading-them $\#$ w_using-a-pdf-reader-plugin 


\title{
The heritage tourist: an understanding of the visitor experience at heritage attractions
}

\author{
Joanna Kempiak ${ }^{a}$, Lynsey Hollywood ${ }^{a}$, Peter Bolan ${ }^{a}$ and Una McMahon-Beattie ${ }^{b}$
}

aDepartment of Hospitality and Tourism Management, Ulster Business School, Ulster University, Coleraine, UK; ${ }^{b}$ Department of Hospitality and Tourism Management, Ulster Business School, Ulster University, Belfast, UK

\section{ABSTRACT}

This study seeks to explore the visitor experience at heritage sites pre, during and post visit. A conceptual model depicting the heritage visitor experience was proposed. A self-administered survey $(n=195)$ was completed by visitors at six heritage sites across Northern Ireland. Visitor characteristics and preexperience were analysed and results showed that heritage visitors are primarily motivated by recreation and base their visitation decision on advice from friends and family. Results from the exploratory factor analysis showed that audio and visual communication, atmospherics, on-site engagement, information and heritage preservation were the most influential factors during a visit. Post-experience results indicate that $54 \%$ of the sample was satisfied with their visit and $85 \%$ would revisit the heritage site. The final model suggests a range of factors which positively contribute to the visitor experience at heritage sites though this requires further testing.

\section{ARTICLE HISTORY}

Received 22 July 2016

Accepted 26 December 2016

\section{KEYWORDS}

Heritage tourism; visitor experience; tourist motivation; decision-making; satisfaction

\section{Introduction}

The dynamic nature of the tourism industry combined with advances in transport, technology and media communications has resulted in changes in tourist needs and preferences for travel. Nowadays, tourists are less interested in conventional, mass 'sea, sun and sand' holidays and instead are demanding more memorable and engaging travel experiences (Timothy 2011; OECD 2012). In response to tourist demands the industry has sought to provide visitors with alternative or thematic types of tourism experiences (Stamboulis and Skayannis 2003). One such form of tourism which has grown in popularity is heritage tourism, often used interchangeably with the term cultural tourism (Richards and Wilson 2006). Heritage tourism is defined by Richards $(2001 \mathrm{~b}, 37)$ as 'the movement of persons to cultural attractions away from their normal place of residence, with the intention to gather new information and experiences to satisfy their cultural needs. This growing demand for heritage tourism is a result of changes in customers' tastes and preferences as visitors are seeking more diversified, engaging and intellectual experiences (Timothy 2011). Visitor demand for heritage tourist attractions is sizeable with approximately $40 \%$ of global tourism relating to heritage/cultural based travel in 2007 (OECD 2009; UNWTO 2010; cited in Shore 2010). Thus, heritage tourism is considered as one of the fastest growing sectors within the tourism industry bringing significant contribution to local and national economies. 
Some critics have challenged the investment required in heritage attractions as these types of visits are often viewed as a short-lived experience. Ashworth $(2009,7)$ suggests, 'the tourist experience of local heritage is short, with visits to particular towns measured in hours and to a particular site or exhibit better measured in minutes or even seconds. However, research within this area should not be neglected as knowing and understanding the mind-set of heritage visitors is key to informing the development of successful management plans and marketing strategies surrounding the attraction (Richards 2001a; Poria, Butler, and Airey 2004; Daengbuppha, Hemmington, and Wilkes 2006).

This paper will examine the key factors influencing the visitor experience pre, during and post visit at heritage attractions. The study seeks to take a holistic perspective of the visitation experience by evaluating the characteristics of the heritage visitor, identifying the motivational and decision-making drivers influencing the visitation choice, exploring the factors influencing the satisfaction of the visit and determining the likelihood of a revisit to the attraction.

\section{Literature review}

According to Palmer $(1999,315)$ heritage was 'the "buzz" word of the 1990s'. Fyall and Garrod (1998) viewed heritage tourism from an economic perspective, suggesting that it is a process during which both environmental and socio-cultural resources are used for the purpose of attracting the visitor. However, Poria, Butler, and Airey $(2003,1048)$ defined heritage tourism as, a subgroup of tourism, in which the main motivation for visiting a site is based on the place's heritage characteristics according to the tourists' perception of their own heritage'. Timothy (1997) purports that heritage visitor attractions (HVA) should be considered at four levels: (1) world; (2) national; (3) local and; (4) personal. For the purposes of this review the literature will attempt to address studies relating to all four levels while the study will narrow its focus towards local and national heritage.

HVA are a vital element of the sector often perceived as a 'pull' factor attracting visitors to a destination for a variety of reasons. When categorising heritage attractions, it is crucial to take into consideration the difference between HVAs and World Heritage Sites (WHS). The core characteristic and obligatory aspect of WHS is fact that these places and sites (natural and built alike) are recognised by UNESCO as properties with outstanding universal value' and are inscribed on the World Heritage list (Breakey 2012, 83). In addition, a site has to meet certain criteria in order for it to be

30 listed by UNESCO. It could be argued that such sites are likely to have a more significant impact on visitors' intention to visit as well as their experience during and post-visit evaluation, compared to a local or national HVA. Moreover, it could impact on visitor behaviour patterns such as the length of visit. Nevertheless, it is essential to highlight that this literature focuses on local and national HVAs which are not considered as WHS.

Furthermore, de Rojas and Camarero (2008) emphasised the link between heritage site attributes, their setting and their impact on visitors' engagement, satisfaction and the quality of experience which according to Moscardo $(1996,378)$, 'should be placed at the centre of any heritage management process'. McIntosh (1999) and Apostolakis and Jaffry (2005) drew attention to the importance of the physical environment but emphasised that this was only one of several factors motivating visitors to visit the attraction. These authors highlighted this shift towards developing an HVA which focuses on enhancing the overall visitor experience. Therefore, this paper purports that understanding the visitor experience at national and local HVAs is a vital component in the decision-making process for those involved in the management of such tourist sites.

\subsection{The heritage visitor experience}

The underpinning concept of the experience economy (Pine and Gilmore 1999) notes that the tourism industry and heritage tourism sector are strongly associated with the consumption of an experience 
(Chen and Chen 2010). Keeping in mind the dynamic nature of the industry and its technological advances, it is essential to take into consideration the evolution of experience concepts. As stated by Richards $(2012,16)$, critics have pointed out that the experience economy concept pays too much attention to the role of the producer in providing experiences and not enough attention to the role of the consumer in creating, shaping and adapting their own experience.

Richards (2012) proposes an evolutionary model of the tourism consumption experience wherein the concept of co-creation and communities play a key role. Unlike in the experience economy where the focus is placed on staging of the experience, the co-creation process enables collaboration between businesses and consumers, and encourages both parties to take an active part in a design and implementation of the experience (Prahalad and Ramaswamy 2004a). While the concept of co-creation will not be directly explored in this study, an understanding of visitor's behaviours at a local and/or national HVA is sought.

As suggested by Falk and Dierking (1992) a visitation to a heritage site involves engagement with a complex range of interrelated components including: personal (an individual's characteristics, i.e. motivations and interests), social (experience and behaviours varying i.e. accordingly to travelling party), and the physical setting (the heritage setting i.e. exhibitions, atmospherics). Pine and Gilmore $(1999,98)$ stated that 'an experience occurs when a company intentionally uses services as the stage, and goods as props, to engage individual customers in a way that creates a memorable event'. This definition highlights several core aspects - intentional use, engagement and a memorable moment. Moreover, the authors identified four dimensions of experiences (entertainment, education, aesthetics and escapism), based on a visitor's level of participation and the form of the experience itself.

The four realms of the experience model suggest that visitors/looking for entertainment are passively involved in the experience. Yet it should be remembered that, as highlighted by Hughes and Benn (1995), entertainment is one of the most significant elements within the wide scope of tourism products. On the other hand, when it comes to education, visitors seek to learn something new, hence the process requires a more active involvement and engagement which at the same time gives tourists an opportunity to increase their knowledge. Moreover, both of these dimensions are characterised by absorption, in other words it means that visitors' attention is occupied by a particular experience (Pine and Gilmore 1999). Undoubtedly notable is the fact that entertainment and education are separated, especially while looking at it from a perspective of heritage sites that aims to entertain and educate at the same time. Having considered the fact that both are strong motivational factors, more recent research has identified the emerging trend of edutainment which aims to combine educational technologies and the educational content to take full advantage of their values and enhance the visitor experience (Hertzman, Anderson, and Rowley 2008). Also, the model indicates that an aesthetic dimension relates to passive appreciation of the place and perception of the physical environment. As stated by Oh, Fiore, and Jeoung (2007) the significance of aesthetics is clearly noticeable in the concept of servicescape which often has an impact on visitors' decision-making process when they chose whether to revisit and recommend the site to others. Alternatively, during escapism visitors often 'travel' into a different world hence they are actively involved/ immersed in the experience that enables them to get-away from a daily routine and everyday activities.

\subsection{The tourist pre-visit experience}

While looking at the tourist's pre-visit experience it is essential to examine the key motivations of heritage visitors. McKercher and du Cros (2003) identified five main types of heritage visitors: purposeful, serendipitous, sightseeing, casual and incidental visitors. This typology highlights that visitors vary in their motivations for visiting a heritage site and that learning about heritage itself may not always be a primary motivating factor. Moreover, it indicates that the depth of the visitor experience 
increases proportionally to the importance of culture in the decision-making process. This suggests that visitors who are interested in culture and heritage ought to have more meaningful experience while visiting a heritage site. Keeping in mind the differences amongst groups of heritage tourists, it can be argued that heritage visitors are a diversified market segment. This may result in implications for management as visitors may perceive the heritage site in different ways which may influence their experience and affect their level of satisfaction.

According to Prentice (1993), as cited in Poria, Butler, and Airey (2004, 21), other motivational factors may also include, 'pleasure of viewing, education, information, relaxation, entertainment, and exercise.' Moreover, Jansen-Verbeke and van Rekom (1996) also recognised escapism from daily 10 routine and life enrichment as potential motivating factors, while Kerstetter, Confer, and Graefe (2001) highlighted the interest in history and culture as well as the need for an authentic experience. Furthermore, Timothy and Boyd (2003) identified nostalgia as a reason for visiting heritage sites. Additionally, Swarbrooke and Horner (2007) noted the fulfilment of emotional needs while Moreno Gil and Ritchie (2009) stated curiosity about a place/heritage site has to offer and a desire to do something meaningful should also be considered. Besides, more recently Wu and Wall (2016) identified a range of pull factors (value for money, an excellent environment for family activities, the creative and innovative displays in the museums and the tranquillity of the historical area) and push factors (education and learning, relaxation, creating positive leisure habits, relationship enhancement and extended family obligation). Undoubtedly visitor motivations are diverse and depend on individuals' needs, circumstance, personality and attitude. Nevertheless, it is important to note that tourist's motivations for visiting the attractions can influence their experience, level of engagement and satisfaction (Falk and Dierking 2000).

According to Laws (2001) visitors begin to evaluate their experience before the actual visit starts. The author identified factors influencing visitors' perceptions and expectations, which include previsit information, opening times, parking facilities, accessibility of the site and signage. Additionally, Daengbuppha, Hemmington, and Wilkes (2006) drew attention to the planning stage of the visit. Marty (2007) emphasised the importance of museum websites and information available which very often can influence the desire to visit a site, while according to Anderson and Lucas (1997) and Guisasola et al. (2009) the availability of pre-visit instructional materials and activities (Leighton 2007) can influence the level of visitors' learning outcomes especially when it comes to the younger audience.

\subsection{The tourist experience during the visit}

Having considered that visitor experiences consist of various components, it is also essential to look at factors within the heritage setting that influence the tourist's experience during the visit and impact on their behaviour. The following section discusses visitor management techniques, with an emphasis on the role and importance of availability of information, communication and engagement with tourists as well as the impact of the surrounding environment.

\subsubsection{Information}

One of the core purposes of heritage attractions is to educate visitors through the provision of information which enables visitors to obtain new or expand already existing knowledge (Calver and Page 2013). Undoubtedly guidebooks as well as leaflets and brochures available at the heritage sites play an important role in the acquisition of the primary information. As visitor attractions deal with domestic and international tourists alike, it is crucial that management considers the needs of both segments and provides key information in a variety of languages to satisfy the needs of visitors for whom, for example, English is not a first language (Frochot and Hughes 2000; Pyo 2005). Moreover, it is worth adding that accuracy, clarity and authenticity of information may have an impact on its value as well as visitors' perception, experience and overall satisfaction (Ho and McKercher, 2004). At the same time, the extent to which visitors can increase their knowledge is influenced by the variety and content 
of collections and exhibitions available at the site (Hui and Ryan 2012). However, it is important to note that the heritage setting should be designed in a way which does not 'overload' visitors with the information as this may frustrate and/or discourage them.

\subsubsection{Communication}

Another vital factor affecting visitor experience is the way in which information is communicated and how it is interpreted by the visitor at each site. Some studies revealed that various forms of presentation and interpretation (e.g. interactive media, types of exhibitions, information panels and descriptors) aim to educate, entertain and increase visitors' awareness (Goulding 1999a; Biran, Poria, and Reichel 2006). Cunnell and Prentice (2000) and Leighton (2007) highlighted the value of interpretive media such as information and display boards and stated that both interpretive and interactive sources of information not only stimulate visitors' learning process but also make their experience more memorable. Besides, Moscardo (1996) referred to work of Patterson and Bitgood (1988) who explored correlations between interpretive techniques and visitor behaviour. It was highlighted that interactive exhibitions are perceived as more attractive and tourists are more likely to spend more time exploring the interactive display, rather than observing a traditional static gallery. In addition, the importance of visibility and proximity of artefacts and antiques and its influence on visitor's experience must also be considered.

While considering the value of onsite interpretation Moscardo (1996) argued that there is a significant difference in perception of interest in interpretation (as understanding and acquisition of knowledge) related to certain types of heritage visitor which are classified as mindful and mindless. The study pointed out key qualities of tourists, highlighting differences in behaviour, motivations, feelings, abilities and learning outcomes, between these types of cultural/heritage visitor. Therefore, it can be argued that the more mindful visitor, the greater his experience and higher satisfaction.

\subsubsection{Engagement}

According to Chhabra, Healy, and Sills (2003) performances (i.e. living history and re-enactments) as well as participatory activities (i.e. workshops) not only stimulate learning process but also engage visitors in ways that can positively affect their experience. In addition, Garrod (2008) highlighted that educational facilities positively influence visitors' behaviour by creating a more engaging experience. Page (2011) added that educational facilities also contribute to conservation of heritage as these help visitors to gain a better understanding of an impact of their behaviour and increase awareness of how to preserve both tangible and intangible heritage. This acquisition of knowledge may enhance overall tourist satisfaction. Moreover, keeping in mind the importance of visitor experiences and the shift towards the development of visitor oriented facilities and amenities within heritage attractions, numerous authors have emphasised the vital role of customer service interactions amongst and between customers and employees emphasising the value of the social context within the heritage setting and visitor experience (Rowley 1999; Apostolakis and Jaffry 2005; de Rojas and Camarero 2008). Studies highlight that the 'co-creation experience' enables consumers to personalise their experience thus providing added value, while interactions and dialogue between consumers and organisations ensure quality and can be perceived as a source of competitive advantage (Prahalad and Ramaswamy 2004a, 2004b).

\subsubsection{Atmospherics}

Atmospherics are often referred to as the servicescape which aims to help the visitor gain 'the sense of the place'. As highlighted by Bonn et al. (2007) the physical environment surrounding visitors can either make them approach or avoid an attraction. For example, an exhibit may encourage or discourage a visitor to stay in the museum longer. Bitner (1992) acknowledged that a servicescape has a major impact on visitors' satisfaction and distinguished two core elements: spatial layout and 
functionality as well as elements related to aesthetic appeal. Additionally, Kottasz (2006) highlighted the importance of intangible cues such as mysteriousness, novelty and coherence, while Kotler (1974) referred to: colours, brightness, sizes, shapes, volumes, smells and temperature. While many of these factors are typically found throughout most visitor attractions in totality, they may yield a significant influence on a visitor's overall experience and satisfaction. Wakefield and Blodgett (1994) and Bonn et al. (2007) emphasised that atmospherics have the power to stimulate emotions and affect the mood of visitors; hence managers can use these to influence visitors' behaviour.

\subsection{The tourist post visit experience}

The post visit stage is an inseparable part of the experience when visitors, whether deliberately or not, take into consideration pre-visit expectations, assess various elements of their experience and the overall satisfaction (Calver and Page 2013).

\subsubsection{Visit duration}

The length of time that visitors spend at the heritage attraction may be affected by several factors. A study by Fodness and Murray (1997) highlighted that the visit duration is positively related to the amount and variety of sources of information. On the other hand, Dickinson et al. (2004) stated that the length of the visit affect can be influenced by the type of travel (long holidays or day trip) and scheduled arrangements. In addition, Botti, Peypoch, and Solonandrasana (2008) pointed out that the visit duration may vary accordingly to the visitor's perception of the site. Namely, visitors tend to stay longer at the attraction when they perceive it as the main point of interest, while secondary attractions are usually associated with shorter visits. Moreover, according to Tchetchik, Fleischer, and Shoval (2009) visit duration often depends on visitors' intellectual interest in the heritage site.

\subsubsection{Acquisition of knowledge}

Heritage attractions offer a variety of interpretive media which encourage and stimulate the learning process, and the acquisition of knowledge. As stated by Prentice, Guerin, and McGugan (1998, 15), it is essential 'to distinguish between "knowledge" and "learning": the former being a profile of the visitor when leaving an attraction, and the latter being an outcome of visiting and comprising only part of their knowledge'. According to McIntosh (1999), the heritage setting provides visitors with an opportunity to learn either through an observation or active participation in on site activities while both are crucial elements of the heritage experience. Nevertheless, it is worth noting that as highlighted by Packer and Ballantyne (2002) the extent to which visitors acquire knowledge during a visit is strongly associated with motivational factors as people do not always desire to learn something new and often take trips to heritage sites for entertainment purposes or social interaction.

\subsubsection{Satisfaction}

According to Chen and Chen $(2010,30)$, 'In tourism context, satisfaction is primarily referred to as a function of pre-travel expectations and post-travel experiences.' Several studies revealed that satisfaction is strongly related to and positively associated with service quality and value (Bigné, Sánchez, and Sánchez 2001; Caldwell 2002; de Rojas and Camarero 2008). Moreover, it was highlighted that overall visitor satisfaction often plays an important role in tourists' post visit behaviour and visitors' intentions, namely word of mouth (WOM) and development of expectation (Johns 1999; Baker and Crompton 2000). Visitor satisfaction is therefore of paramount importance to the management of HVAs.

\subsubsection{Revisit}

The outcome of this process of evaluation and reflection upon the visit to a heritage attraction is directly linked to likelihood of revisiting the site, recommending it to others and spreading positive or negative 
WOM (Harrison and Shaw 2004; Rashid 2013). With this in mind it can be argued that it is crucial to create a meaningful, memorable and satisfying experience as this may result in increased visitors' loyalty and gaining a competitive advantage. Moreover, given the rapid rise of social media positive WOM, referrals may play a significant role in influencing a visitor's decision to visit an attraction (Leask, Fyall, and Barron 2013a).

\subsection{Toward the development of a heritage visitor experience model}

Stemming from this review of the literature a range of factors influencing a visitor's experience pre, during and post visitation to a heritage site were identified and a conceptual model of the heritage visitor experience was developed (Figure 1).

This model illustrates that visitors can be motivated by a variety of 'pull' and 'push' factors which influence their intentions to visit to a heritage attraction. During a visit to the heritage site visitors' experience is affected by information, communication, engagement and atmospherics. Moreover, the quality of these components impacts on the depth of the visitor's experience and plays an influential role in the post visit stage when tourists evaluate their overall experience. Depending on how well the heritage site attributes meet the needs of tourists and based on the perceptions (positive and/ or negative) of the visit, visitors will decide whether to recommend the attraction to others and if they are willing to revisit the attraction in the future. A conceptual model depicting the relationship between motivation and decision-making attributes of the visitation experience, overall satisfaction and revisit intention was proposed. Primary research in the form of a self-administered visitor survey was carried out to test the conceptual model and investigate visitors experiences at heritage attractions. This approach and justification for the methods employed are now discussed in detail in the following section.
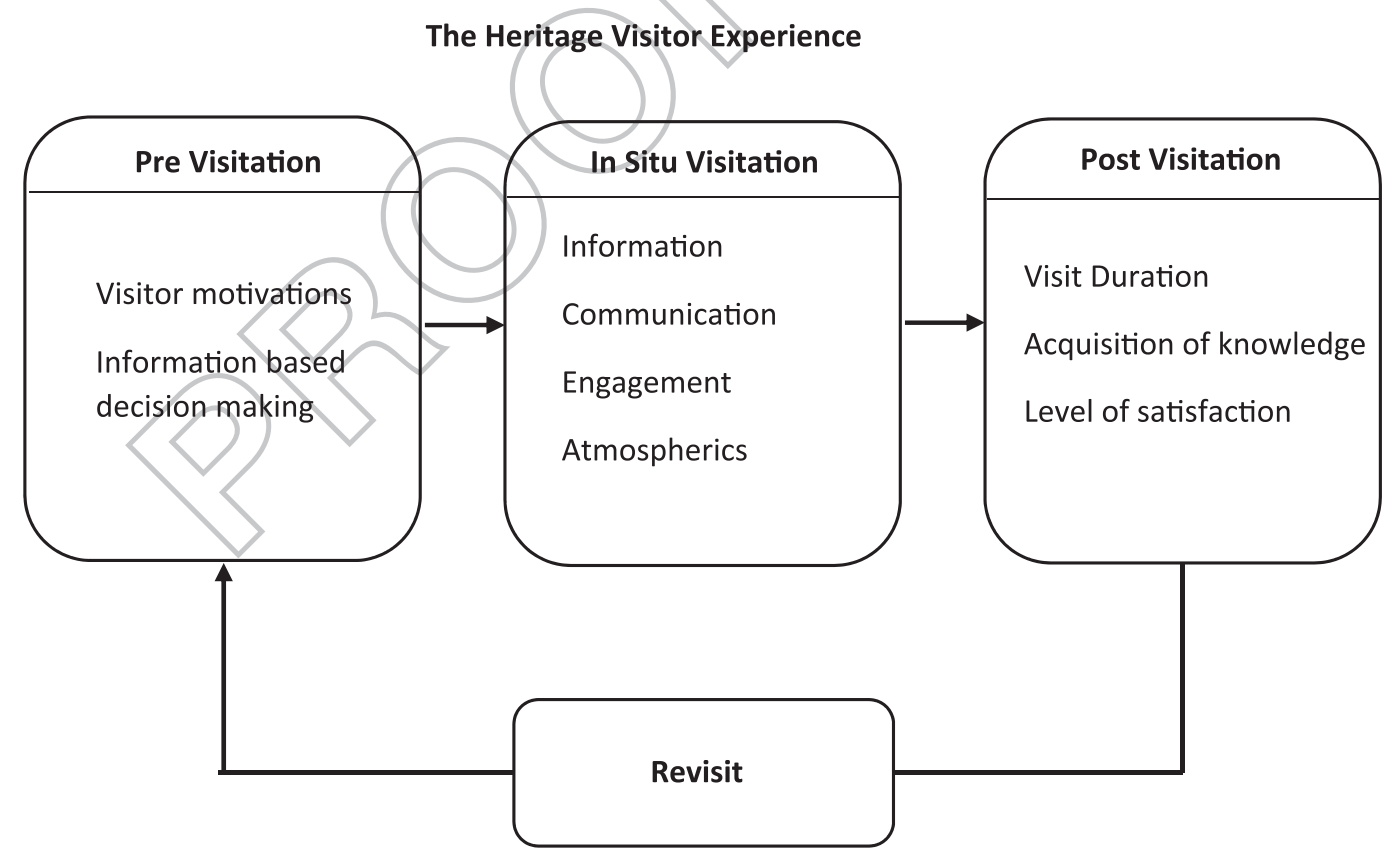

Figure 1. The heritage visitor experience - the conceptual framework. 


\section{Materials and methods}

The overall aim of the study was to examine visitors' experiences of heritage attractions in Northern Ireland in order to gain a better understanding of the heritage visitor. As such the study took a positivistic research approach employing the use of a self-administered questionnaire as the main research instrument.

\subsection{Survey design and development}

Key themes identified from the literature-based conceptual model of the heritage visitor experience were used to guide the structure of the survey instrument. In addition, a scoping exercise was carried out at each heritage site to verify factors informed by the literature and to identify any additional factors which should be included within the final survey instrument.

The first section of the questionnaire was designed to gather demographic information addressing the characteristics of heritage visitors. The second section of the survey investigated the pre-visit experience by addressing motivational and decision-making factors. The third section focused on the experience during the visit addressing the four key areas identified within the conceptual model (information, communication, engagement and atmospherics). Questions were measured on a fivepoint Likert scale ranging from 1 (not at all important) to 5 (extremely important). The final section of the survey addressed post visit evaluations while other questions within this section included enjoyment and revisit intentions.

\subsection{Survey administration}

20 The selection of research sites was based on the Northern Ireland Visitor Attraction Survey (DETI, 2013) and included attractions of historical, educational or industrial nature which ranked within the top five, most visited, heritage sites across categories: Museums and Art Galleries, Historic Properties, Visitor Heritage Centres, attracting the highest number of visitors annually. Moreover, selection of sites within different categories aimed to provide the opportunity for generalisation of the results. The six heritage attractions chosen as the research sites were: the Old Bushmills Distillery, the Ulster Museum, the Ulster Folk and Transport Museum, Castle Ward, Belfast City Hall and Belfast Castle.

\subsection{Participants}

The sample consisted of both domestic and overseas tourists and visitors. Over 200 took part in the survey. A total of 195 usable responses were obtained, which constituted a response rate of 93\%. Mundfrom, Shaw, and Ke (2005) and Pearson and Mundform (2010) referred to the work of Comrey and Lee (1992) who indicated that 200 is regarded as a fair sample when conducting factor analysis. Moreover according to Worthington and Whittaker $(2006,817)$ 'sample sizes of 150-200 are likely to be adequate with data sets containing communalities higher than 0.50'. Having considered the overall number of potential respondents and the final sample size the research should be considered as exploratory. Sampling took place in order to achieve a balance of participants across each of the heritage sites, while each participant was approached at different exit zones at the site.

\subsection{Data analysis}

All data was coded and put into SPSS (v20) for analysis. The data was checked for coding as well as the measures of central tendency and dispersion. To identify outliers and the normal distribution of the Likert scale questions, the skewness and kurtosis measures were used. Data was then analysed using univariate and bivariate analysis followed by exploratory factor analysis (EFA). 
Table 1. Exploratory factor analysis.

\begin{tabular}{|c|c|c|c|c|c|c|}
\hline Heritage visitor experience & Factor 1 & Factor 2 & Factor 3 & Factor 4 & Factor 5 & Cronbach's alpha \\
\hline Audio-visual exhibitions & 0.849 & & & & & 0.900 \\
\hline Animations & 0.804 & & & & & \\
\hline Sound \& recordings & 0.779 & & & & & \\
\hline Interactive exhibitions & 0.743 & & & & & \\
\hline Timelines & 0.653 & & & & & \\
\hline Full-scale reconstructions & 0.579 & & & & & \\
\hline Information boards & 0.478 & & & & & \\
\hline Labels \& descriptors & 0.419 & & & 0.410 & & \\
\hline Spatial layout \& design functionality & & 0.838 & & & & 0.906 \\
\hline Lighting & & 828 & & & & \\
\hline Décor & & 0.791 & & & & \\
\hline Visitor route & & 0.769 & & & & \\
\hline Ambience & & 0.763 & & & & \\
\hline Internal signage & & 0.620 & & & & \\
\hline Interactive and "hands on" workshops & & & 0.802 & & & 0.888 \\
\hline Educational games & & & 0.801 & & & \\
\hline Dressing up & & & 0.800 & & & \\
\hline Kids'zones & & & 0.753 & & & \\
\hline Re-enactment \& living history & & & 0.711 & & & \\
\hline Special events & & & 0.603 & & & \\
\hline The availability of knowledgeable staff & & & & 0.793 & & 0.771 \\
\hline Accuracy of information & & & & 0.717 & & \\
\hline Clarity of information & & & & & & \\
\hline $\begin{array}{l}\text { The availability of information in different } \\
\text { languages }\end{array}$ & & & & & & \\
\hline The availability of guidebooks \& leaflets & & & & 0.614 & & \\
\hline Visibility of antiques & & & & & 0.788 & 0.839 \\
\hline Conservation of antiques & & & & & 0.732 & \\
\hline The use of personal stories & & & & & 0.678 & \\
\hline The use of myths \& legends & 0.479 & & & & 0.554 & \\
\hline
\end{tabular}

\section{Results}

The study revealed that females (55\%) represented a larger proportion of the surveyed visitors than males (45\%). The majority of tourists were between 25 and 54 years old (68\%) while visitors within 15-24 age groups (9\%) were the smallest population. Over $74 \%$ of visitors who participated in the study have either a full time or a part time job. With regards to the level of education, the study shows that over a third (34\%) of visitors at heritage attractions have an undergraduate and $21 \%$ a postgraduate degree. Moreover, a majority of tourists visited a site with a family member (39\%) or a partner (30\%).

\subsection{Motivations and pre-visit decision-making}

The study showed that the main motivating factor was for a recreational visit (41\%) and to learn about heritage (19\%). Interestingly, one of the lowest ranked motivations was that of nostalgia (4\%). However, it can be assumed that the result is related to the nature of the experience offered at the heritage site and content of the galleries which not always evoked sentimental emotion. Furthermore, results revealed the main factor influencing the decision-making of visitors was advice from friends and relatives. The results also showed that $25 \%$ of the sample had made a previous visit to the site influencing their decision to revisit the site. Surprisingly, results indicated that social media (2\%) was the least influential factor in a visitors pre-visit decision, thus highlighting an area for an improvement.

\subsection{The tourist experience during the visit}

To investigate the factors influencing a visitor's experience, participants were asked to indicate the importance of a variety of items on a Likert scale. The results are based on the outcome of the EFA which was conducted to explore the structure of the data and identify a model for the 33 heritage visitor experience items. 
The Kaisere-Meyere-Olkin Measure of Sampling Adequacy (KMO) value was 0.880 exceeding the recommended value of 0.6 and Bartlett's Test of Sphericity reached statistical significance $(p=0.000)$ which confirmed that factor analysis was an appropriate method to generate a new set of variables.

Principal component analysis showed a presence of seven components with eigenvalues greater than 1 explaining $35.25,9.01,7.18,6.06,4.95,4.00$ and 3.14\% of the variance respectively. An investigation of the scree plot and parallel analysis indicated that only five of all factors should be retained. The five component solution explained a total of $62.44 \%$ of the variance. To help in the interpretation of extracted components Varimax rotation was performed and problem items were removed one at a time. Moreover, a reliability of each factor was tested using Cronbach's a coefficient (Table 1).

Table 1 shows the EFA with the five factor solution where the components were named based on the core aspect reflecting the nature of the factor.

Factor one Audio and Visual Communication consisted of nine items related to the forms, types of exhibitions and sources of knowledge. Amongst the variety of interpretive media four items had a factor loading above 0.7 . These include audio-visual exhibitions, animations, sound and recordings 15 and interactive exhibitions suggesting that interactive and digital media are vital forms of communication of the heritage content and play a major role in visitor experience. Moreover, visitors perceived information boards (mean $=3.6$ ) and labels and descriptors (mean $=3.5$ ) as the most important during their visit to heritage sites.

Factor two Atmospherics consisted of six items relating to the environment surrounding the heritage site. Spatial layout \& design functionality had the highest loading (0.838), while visitor route $($ mean $=3.92)$ and ambience $($ mean $=3.92)$ were also rated as the most important factors affecting visitors' experience. Therefore, it could be argued that the heritage setting, which plays a crucial role in visitors' perception of the site, is highly valued and atmospherics have a significant impact on visitors' experience.

The third factor On-site Engagement consisted of six items. High factor loadings of interactive and 'hands on' workshops might suggest that visitors are willing to participate in on site activities and look for the opportunity to interact with the heritage setting. The fact that the factor related to the use of educational games, dressing up and kids' zones suggesting that heritage sites should have a family orientation especially considering that recreational trips and taking friends and relatives on a visit were important motivational factors. It is worth noting that amongst all of these components, special events (mean $=2.25$ ) were rated as the most valuable aspect of the visit to heritage sites. It was closely followed by re-enactments and living history (mean $=2.15$ ) which also contributed to visitor experience and satisfaction.

Factor four Information consisted of six items associated with the availability and accessibility of information. As shown in Table 1, the availability of well-informed staff had the highest factor loading. It indicates that employees play a crucial role in providing information and are a valuable 'source of knowledge'. Moreover, the accuracy (mean $=4.21$ ) and clarity (mean = 4.14) of information were perceived by visitors as the most important factors. Having considered these findings, it could be argued that information and authenticity are highly valued factors affecting visitors' experience.

Lastly, factor five Heritage Preservation consisted of four items related to intangible heritage and conservation. While the visibility of antiques had the highest factor loading, conservation (mean $=3.58$ ) was rated as the most important aspect of the experience. It indicates that visitors, at least to a certain extent, are concerned with the preservation of heritage. The fact that visitors are interested in personal stories shows that tourists want to learn about history; moreover, it supports the previous finding highlighting the need and desire for the authenticity of information. On the other hand the importance of the use of myths and legends suggests that visitors want to immerse into a different world.

Further analysis of the data revealed a number of insights which contributed to understanding the heritage tourist. The Mann-Whitney $\mathrm{U}$ test revealed that the importance of factors such as accuracy [Yes $n=177$, mean rank $=101.81 /$ No $n=18$, mean $\mathrm{rank}=60.53, U=918.5, z=-3.248, p=0.001$, $r=0.23$ ] and clarity of information [Yes $n=177$, mean rank $=100.40 /$ No $n=18$, mean rank $=70.36$, $U=1167.5, z=-2.012 p=0.044, r=0.14]$ had a significant impact on the acquisition of knowledge. 
Moreover a Kruskal-Wallis test showed significant difference between visit duration and: interactive exhibitions $[\times 2(\mathrm{df}=3, n=195)=15.51, p=0.001]$, 'hands on' interactive workshops $[\times 2(\mathrm{df}=3$, $n=195)=24.39, p<0.001]$, re-enactment and living history $[\times 2(\mathrm{df}=3, n=195)=17.65, p=0.001]$.

\subsection{The tourist post visit experience}

Results relating to the heritage visitor experience and their overall satisfaction of the visit were identified.

\subsubsection{Visit duration}

Across all sites the results revealed that the majority of the sample (41\%) spent $1-2 \mathrm{~h}$ visiting the heritage site with only $14 \%$ of respondents who reported spending $3 \mathrm{~h}$ or more at the other heritage sites. The crosstabulation showed that nearly $90 \%$ of respondents who reported to spend less than $1 \mathrm{~h}$ at an attraction were at the site for the first time, while for $59 \%$ of visitors who indicated that their visit duration was $3 \mathrm{~h}$ or longer stated that it was a return visit.

\subsubsection{Acquisition of knowledge}

Nearly all of respondents (91\%) reported that the visitation increased their knowledge of heritage. Moreover, the study showed that knowledge is associated with the type of visitor experience.

\subsubsection{Visitor satisfaction}

20 In relation to how visitors described their experience results showed that over $29 \%$ of respondents indicated that their experience was enjoyable. This was closely followed by informative (29\%) and authentic (21\%) while only $4 \%$ of visitors perceived their visit negatively. Results revealed that $92 \%$ of visitors indicated to be satisfied (55\%) or very satisfied (37\%) with their visit while only $3 \%$ reported to be dissatisfied.

\subsubsection{Return visit and the WOM}

Results showed that $85 \%$ of visitors were willing to return to the heritage attraction they visited, while nearly all respondents (95\%) indicated that they would recommend the heritage site to others. Further analysis showed that there is a significant association between the level of satisfaction 30 and return visit. Additionally, the Mann-Whitney $U$ test revealed a significant difference between the level of satisfaction and revisit as well as recommendation of the heritage attraction. The results highlight the importance of providing visitors with the best possible experience to ensure positive recommendations.

\section{Discussion}

In this study females accounted for a larger proportion of respondents than males. Similar results relating to a distribution of gender within sample were presented in heritage tourism market research (Mintel 2010). However, according to characteristics of respondents in research by Poria, Butler, and 40 Airey (2004) and Apostolakis and Jaffry (2005) males were the dominant group that visited heritage attractions. Moreover survey findings showed that a majority of visitors were between 45 and 54 years old which corresponds with the trend noted by Timothy (2011). Visitors under the age of 24 accounted for the smallest group visiting heritage sites, with similar results were presented by Shore (2010) in study on heritage market characteristics. Results highlight those aged under 24 as an opportune market within heritage tourism. Employing tactics like edutainment may provide a means to engage this type of visitor during the visit experience.

Having considered the fact that a majority of visitors completed higher education, the study findings supports the work of Timothy and Boyd (2003) and Kerstetter, Confer, and Bricker (1998) who argue that heritage visitors tend to be better educated. Results were also aligned to that of Sharifi-Tehrani, 
Verbič, and Chung (2013) who identified an association between level of education and visitors' willingness to pay for an experience. A relatively small proportion of visitors indicated travelling in organised tours or groups meaning the majority of visitors were independent travellers. These results are similar to studies by Gaffar, Prateep Wetprasit, and Setiyorini (2011) and Ashworth (2004) who noted that the independent travellers accounted for a majority of visitors at heritage sites. Visitors classified as independent travellers will have a greater degree of freedom to explore the heritage site which may increase visitor satisfaction and enhance an individual's knowledge and learning of heritage. The analysis showed that visitors living in Northern Ireland are more likely to stay at the heritage site longer than international visitors. This however might be related to the fact that often international visitors have pre-planned trip arrangements hence their time is more restricted. Additionally, it can be seen that visitors who described their experience as an interactive one spent $3 \mathrm{~h}$ or more at the site. This study revealed that younger participants were mainly motivated by recreational needs as well as curiosity toward finding out what the attraction has to offer. At the same time more mature visitors visited heritage attractions for nostalgic reasons. These findings support similar results from a study by Goulding (1999b) who indicated that the tourists were primarily motivated by past memories are mainly the 'grey' market. Moreover, it was interesting to note that nostalgia was a more popular reason to visit an attraction among domestic participants than international participants. Therefore, it could be theorised that international tourists may not feel a sense of belonging or an attachment to the attraction therefore more likely to be motivated by factors such as learning or seeing what the attraction has to offer.

The findings indicated that the majority of participants who were motiyated to visit the attraction to enhance their learning or increase their knowledge about heritage had higher education qualification at either undergraduate or postgraduate degree level. Schouten $(1995,260)$ considered the main reason to visit a heritage site was 'to learn something new' as a myth and argued that visitors' behaviour, 'is more akin to window-shopping on a Saturday afternoon than to the intelligent acquisition of new knowledge.' Alternatively, the majority of tourists with a lower level of education were more interested in the social aspects of the visitor experience, for example, spending time with friends and relatives. These findings highlight the importance of social interaction acting as a motivating factor among lower educated participants.

WOM recommendations from family and friends played a vital role in visitors' decision-making when planning a visit. Often these types of recommendations are considered as the most reliable, trusted and powerful source of information which often influences a visitor's expectations (de Rojas and Camarero 2008). A previous visit to the attraction was another key factor influencing the decision-making of the visitor. Undoubtedly it is of vital importance to managers and marketers to get an in depth understanding of the sources of information that influence visitor's decision-making process before visiting a heritage attraction (McCain and Ray 2003). Having considered the fact that large proportion of international participants within the sample were older it was not surprising that they preferred to use tourist guidebooks suggesting that they may feel more comfortable using more 'old fashioned' sources of information. Given today's media savvy visitor it was surprising to find that social media was the least used source of information that influenced participants' decision-making process. With this in mind it is essential that heritage attractions evaluate their investment in the pre-visit experience to ensure that are effectively targeting the right tourist and are maximising their opportunity to attract wider market segments, especially the younger tech-savvy generation Y (Leask, Fyall, and Barron 2013b).

Findings relating to the visitor's experience during the visit identified a five factor solution (audio and visual communication; atmospherics; on-site engagement; information and; heritage preservation). The results revealed, the main factors influencing participants' experience at a heritage attraction were related to the accuracy and clarity of the information provided which are similar to the work of Jewell and Crotts (2009). This study indicated that visitors who rated these factors as unimportant did not report an increase in knowledge. In addition, visitors who ranked the provision of labels and descriptors, information boards and social interactions amongst customers and employees as important 


\section{The Heritage Visitor Experience}

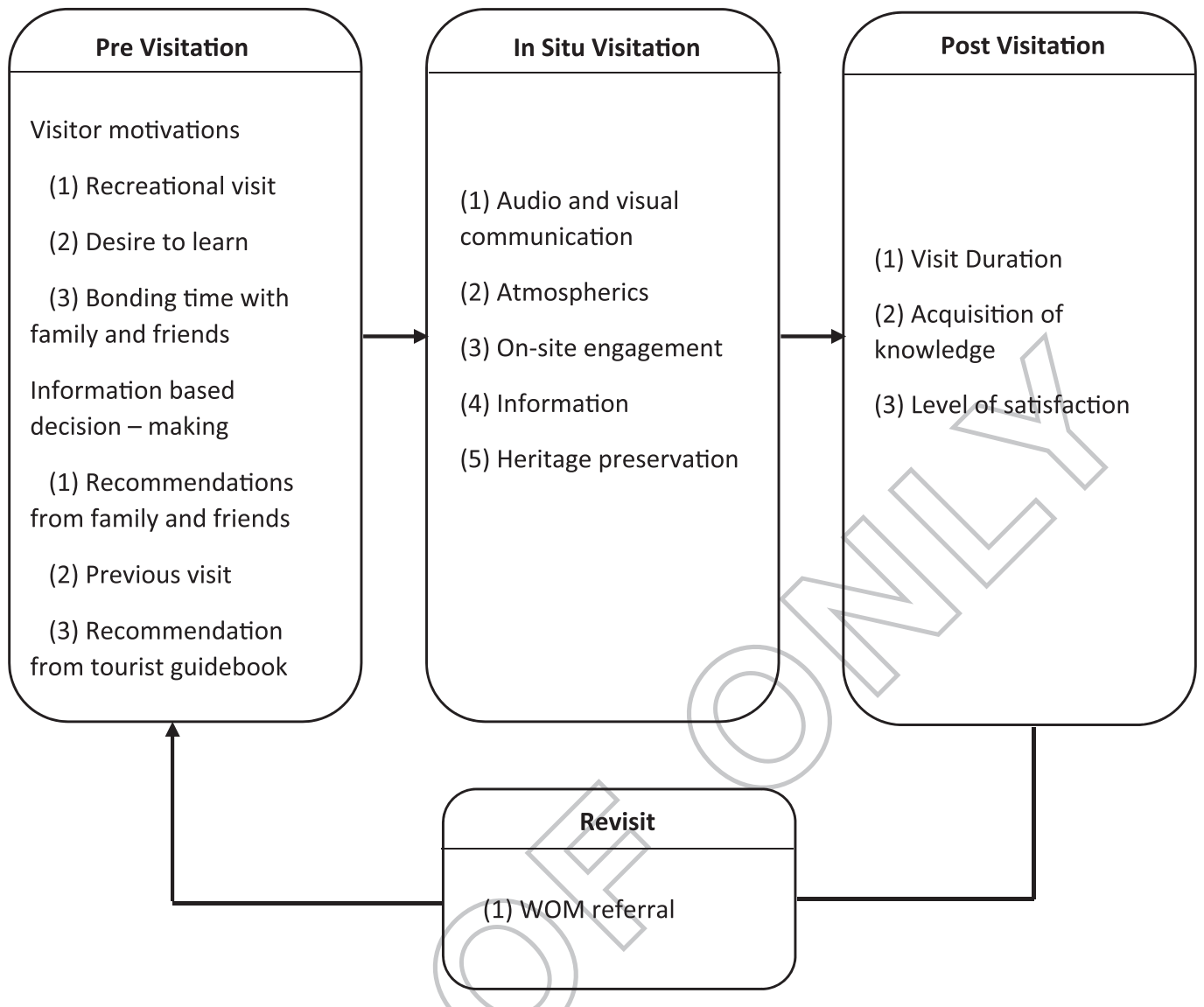

Figure 2. The heritage visitor experience model.

tended to stay longer at the site. These findings emphasised the need for further research into whether a relationship exists between the provision of information and the quality and value of the heritage visitor experience as well as benefits (i.e. the acquisition of knowledge).

Furthermore, the study showed that certain forms of communication (i.e. interactive exhibitions) and engagement (i.e. workshops and special events) are in the interest of visitors. It can be argued that an increase in the use of technology empowers modern consumers and facilitates co-creation of tourism experiences (Binkhorst 2006; Tussyadiah and Fesenmaier 2009). A study by Neuhofer, Buhalis, and Ladkin (2013) highlighted the importance of technology in the creation of enhanced experiences and higher value for the tourist (Gretzel and Jamal 2009). This highlights the need for further research into how co-creation can add value to the visitor experience at a HVA. The findings suggest that visitors seek and value the opportunity to be actively involved in the experience and interact with the heritage setting. Such forms of communication can help to enhance a visitor's experience and stimulate the learning process. Moscardo (1996) referred to work of Patterson and Bitgood (1988) who indicated that interactive exhibitions enhance tourists' education and attract bigger attention. As a result visitors tend to spend more time than in comparison to traditional displays. Nevertheless, Petrelli et al. (2013) highlighted several weaknesses associated with interactive attributes on sites which involved queuing to get access to a particular interactive display and disruption in social interactions. This finding raises the question of whether visitors paying shorter 
visits to a heritage attraction have enough time to engage and explore the site fully. Therefore, findings suggest that the visit duration time could be increased by enhancing the level of on-site engagement and investing in the audio and visual communication within the visitor experience to involve visitors in the heritage experience.

The results showed that higher levels of satisfaction meant visitors are more likely to revisit and recommend the heritage site. Similar findings were noted by Cronin, Brady, and Hult (2000) who highlighted the positive relationship between satisfaction and intentions to return. Nevertheless, it is worth noting that a study by Nowacki (2009) showed that return visits and referrals often depend also on benefits gained from a visit and perception of the site quality.

Having considered the results of this study which examined the factors influencing a heritage visitors experience and their importance the conceptual model of the heritage visitor experience was further developed. This conceptual model is based on foundations of the framework presented in the literature review, but has been further expanded upon using the survey findings. The newly revised conceptual model is presented in Figure 2.

This Heritage Visitor Experience model (Figure 2) presents a more detailed revised version stemming from the earlier conceptual model (Figure 1). Based on the research findings, the model provides a more comprehensive representation of the factors at play. This commences with pre-visit motivations and decision-making through to the actual heritage experience in situ and the key factors which create the experience for the visitor; followed by post-visit aspects with further factors such as WOM referral driving the tourist to revisit the heritage site at some future date.

\section{Recommendations for further research}

As discussed by Park (2014) contemporary tourists are not satisfied with merely consuming products and services but increasingly seek unique and memorable experiences and this is especially prevalent for HVAs. It is believed that the results of this study will encourage further investigation into visitor experiences within the field of heritage tourism. Further testing of the proposed conceptual model (Figure 2) is required, with the development of measurement scales relating to the motivations and decision-making factors influencing pre-visit choices of heritage destinations. An examination of visitors' expectations prior to the visit and post visit could also provide further insight into whether the expectations of the heritage visitor are being met and indeed fully catered to. Future studies could use participant observation to investigate visitors' on site behaviour patterns, engagement and interaction with the heritage setting. Lastly, further investigation into how heritage attractions could be promoted to younger generations to encourage visitation should be considered. The future of heritage sites as tourist attractions is highly dependent on such enticement and engagement with younger demographics and the experiences which are provided at these sites.

\section{Conclusions}

The research aimed to examine visitors' experiences of heritage attractions in Northern Ireland. A review of literature highlighted the growing interest in heritage as a form of tourism and how it plays a significant role in a destination's image. As such this study evaluated the importance of heritage tourism, explored the characteristics of heritage visitors, and investigated the visitor experience at heritage attractions (pre, during and post visit). Key aspects of this visitation cycle have been represented on the model in Figure 2.

An investigation of motivations and visitor's behaviour patterns revealed that the most common reason for visiting the heritage site was recreation with the desire to gain more knowledge and learn about the heritage being a secondary factor. In addition, the study revealed that WOM recommendations play a vital role in the pre planning decision of heritage visitors. The research identified five factors which enhance the experience of the heritage visitor during their visit (audio and visual communication; atmospherics; on-site engagement; information and; heritage preservation). Moreover, the study 
identified a relationship between knowledge acquisition and satisfaction which subsequently would lead to a WOM referral or a return visit to the site. Having considered the complexity and potential of the heritage market, further research into the field is essential to gain a better understanding of how to effectively target the heritage visitor and provide them with a meaningful and memorable experience.

\section{Disclosure statement}

No potential conflict of interest was reported by the authors.

\section{Notes on contributors}

10 Joanna Kempiak (corresponding author) is a $\mathrm{PhD}$ student within the Department of Hospitality \& Tourism Management, Ulster University Business School, Ulster University (Northern Ireland). Her main research interests include consumer behaviour within tourism. Her Masters research focused on heritage tourism and $\mathrm{PhD}$ research investigates consumers' use of digital media within the food tourism context.

Lynsey Hollywood is a lecturer in Consumer Management and Food Innovation in the Department of Hospitality \& Tourism Management at Ulster University. She holds a $\mathrm{PhD}$ in Marketing from Ulster University and has published widely on consumer behaviour and food choice in journals and conference in the UK and internationally. Lynsey currently supervises four $\mathrm{PhD}$ students all completing projects in the areas of food poverty, agri-food marketing and food tourism. Her research skills include: focus groups, interviews, observation studies and survey design.

Peter Bolan is a senior lecturer in the Department of Hospitality \& Tourism Management. Peter is the Course Director for the BSc Hons International Travel \& Tourism Management Degree at Ulster University. His main research interests include film and media induced tourism, eBusiness, social media and mobile applications in tourism, golf tourism and food tourism. Recently he has been involved in an EU funded project to develop next generation mobile phone app's for interpretive information at visitor attractions.

Una McMahon-Beattie is the Head of Department for Hospitality \& Tourism Management. Her research interests include hospitality and event marketing, revenue management and hospitality and tourism futures. She has published widely in journals, books and conferences in the UK and internationally. Una is the author/editor of a number of books including, The Future of Events and Festivals and The Future Of Food Tourism: Foodies, Experiences, Exclusivity, Visions And Political Capital.

\section{References}

Anderson, D., and K. Lucas. 1997. "The Effectiveness of Orienting Students to the Physical Features of a Science Museum prior to Visitation." Research in Science Education 27 (4): 485-495.

Apostolakis, A., and S. Jaffry. 2005. "A Choice Modeling Application for Greek Heritage Attractions." Journal of Travel Research 43 (3): 309-318. doi:10.1177/0047287504272035.

Ashworth, G. J. 2004. "The Blue - Grey Transition: Heritage in the Reinvention of the Tourism Resort." The Critical Tourism Studies Conference Series, Dubrovnik.

Ashworth, G.J. 2009. "Do Tourists Destroy the Heritage They Have Come to Experience?” Tourism Recreation Research $34(1): 79-83$.

Baker, D. A., and J.L. Crompton. 2000. "Quality, Satisfaction and Behavioral Intentions." Annals of Tourism Research 27 (3): 785-804. doi:10.1016/S0160-7383(99)00108-5.

Bigné, J. E., M. I. Sánchez, and J. Sánchez. 2001. “Tourism Image, Evaluation Variables and after Purchase Behaviour: Inter-relationship." Tourism Management 22 (6): 607-616. doi:10.1016/S0261-5177(01)00035-8.

Binkhorst, E. 2006. "The Co-creation Tourism Experience." Paper presented at the XV International Tourism and Leisure Symposium, Barcelona.

Biran, A., Y. Poria, and A. Reichel. 2006. "Heritage Site Management: The Link between Visitors' Pre-visit Perceptions, Motivations and Expectations." Anatolia 17 (2): 279-304. doi:10.1080/13032917.2006.9687190.

Bitner, M. J. 1992. "Servicescapes: The Impact of Physical Surroundings on Customers and Employees." Journal of Marketing 56: 57-71.

Bonn, M. A., S. M. Joseph-Mathews, M. Dai, S. Hayes, and J. Cave. 2007. "Heritage/Cultural Attraction Atmospherics: Creating the Right Environment for the Heritage/Cultural Visitor." Journal of Travel Research 45 (3): 345-354. doi:10.1177/0047287506295947.

Botti, L., N. Peypoch, and B. Solonandrasana. 2008. "Time and Tourism Attraction." Tourism Management 29 (3): 594-596. doi:10.1016/j.tourman.2007.02.011. 
Breakey, N. M. 2012. "Studying World Heritage Visitors: The Case of the Remote Riversleigh Fossil Site." Visitor Studies 15 (1): 82-97.

Caldwell, N. 2002. “(Rethinking) the Measurement of Service Quality in Museums and Galleries.” International Journal of Nonprofit and Voluntary Sector Marketing 7 (2): 161-171. doi:10.1002/nvsm.176.

Calver, S. J., and S. J. Page. 2013. "Enlightened Hedonism: Exploring the Relationship of Service Value, Visitor Knowledge and Interest, to Visitor Enjoyment at Heritage Attractions." Tourism Management 39: 23-36. doi:10.1016/j. tourman.2013.03.008.

Chen, C., and F. Chen. 2010. "Experience Quality, Perceived Value, Satisfaction and Behavioral Intentions for Heritage Tourists." Tourism Management 31 (1): 29-35. doi:10.1016/j.tourman.2009.02.008.

Chhabra, D., R. Healy, and E. Sills. 2003. "Staged Authenticity and Heritage Tourism." Annals of Tourism Research 30 (3): 702-719. doi:10.1016/S0160-7383(03)00044-6.

Comrey, A., and H. Lee. 1992. A first course in factor analysis. Hillsdale: Erlbaum.

Cronin Jr., J. J., M. K. Brady, and G. T. M. Hult. 2000. “Assessing the Effects of Quality, Value, and Customer Satisfaction on Consumer Behavioral Intentions in Service Environments.” Journal of Retailing 76 (2): 193-218. doi:10.1016/ S0022-4359(00)00028-2.

Cunnell, D., and R. Prentice. 2000. “Tourists' Recollections of Quality in Museums: A Servicescape without People?” Museum Management and Curatorship 18 (4): 369-390. doi:10.1016/S0260-4779(00)00009-1.

Daengbuppha, J., N. Hemmington, and K. Wilkes. 2006. "Using Grounded Theory to Model Visitor Experiences at Heritage Sites." Qualitative Market Research: An International Journal 9 (4): 367-388. doi:10.1108/13522750610689096.

DETI. (2013). Northern Ireland Visitor Attraction Survey (January-December 2012). Available from: http://www.detini. gov.uk/deti-stats-index/tourismstatistics/visitor_attraction_survey-2.htm

Dickinson, J. E., S. Calver, K. Watters, and K. Wilkes. 2004. "Journeys to Heritage Attractions in the UK: A Case Study of National Trust Property Visitors in the South West." Journal of Transport Geography 12 (2): 103-113. doi:10.1016/j. jtrangeo.2003.12.002.

Falk, J. H., and L. D. Dierking. 1992. The Museum Experience. Washington, DC: Whalesback.

Falk, J. H., and L. D. Dierking. 2000. Learning from Museums: Visitor Experiences and the Making of Meaning. Plymouth: AltaMira Press.

Fodness, D., and B. Murray. 1997. “Tourist Information Search.” Annals of Tourism Research 24 (3): 503-523. doi:10.1016/ S0160-7383(97)00009-1.

Frochot, I., and H. Hughes. 2000. "HISTOQUAL: The Development of a Historic Houses Assessment Scale." Tourism Management 21 (2): 157-167. doi:10.1016/S0261-5177(99)00045-X.

Fyall, A., and B. Garrod. 1998. "Heritage Tourism: At What Price?" Managing Leisure 3 (4): $213-228$. doi:10.1080/136067198375996.

Gaffar, V., H. P. Prateep Wetprasit, and D. Setiyorini. 2011. "Comparative Study of Tourist Characteristics on Cultural Heritage Tourism Sites: Survey on Tourist in Indonesia and Thailand Heritage Sites." Journal of Tourism Hospitality and Culinary Arts 3 (3): 53-68.

Garrod, B. 2008. “Managing Visitor Impacts." In Managing Visitor Attractions: New Directions. 2nd ed., edited by A. Fyall, B. Garrod, and A. Leask, 165-180. Oxford: Butterworth-Heinemann.

Goulding. C. 1999a. "Interpretation and Presentation.” In Heritage Visitor Attractions: An Operation Management Perspective, edited by A. Leask and I. Yeoman, 54-67. London: Cassell.

Goulding, C. 1999b. "Heritage, Nostalgia, and the 'Grey' Consumer." Journal of Marketing Practice: Applied Marketing Science 5 (6/7/8): 177-199

Gretzel, U., and T. Jamal. 2009. "Conceptualizing the Creative Tourist Class: Technology, Mobility, and Tourism Experiences" Tourism Analysis 14 (4): 471-481.

Guisasola,J., J. Solbes, J. Barragues, M. Morentin, and A. Moreno. 2009. “Students' Understanding of the Special Theory of Relativity and Design for a Guided Visit to a Science Museum.” International Journal of Science Education 31 (15): 2085-2104. doi:10.1080/09500690802353536.

Harrison, P., and R. Shaw. 2004. "Consumer Satisfaction and Post-purchase Intentions: An Exploratory Study of Museum Visitors." International Journal of Arts Management 6 (2): 23-32.

Hertzman, E., D. Anderson, and S. Rowley. 2008. "Edutainment Heritage Tourist Attractions: A Portrait of Visitors' Experiences at Storyeum." Museum Management and Curatorship 23 (2): 155-175. doi:10.1080/09647770802012227.

Ho, P. S. Y., and B. McKercher. 2004. "Managing Heritage Resources as Tourism Products." Asia Pacific Journal of Tourism Research 9 (3): 255-266. doi:10.1080/1094166042000290655.

Hughes, H., and D. Benn. 1995. "Entertainment: Its Role in the Tourist Experience." In Leisure and Tourism: Towards the Millennium. Vol. 2, edited by D. Leslie, 11-21. Eastbourne: Leisure Studies Association.

Hui, C., and C. Ryan. 2012. "Issues in Museum Management Policies: Evidence from Xian, China." Visitor Studies 15 (1): 62-81. doi:10.1080/10645578.2012.660843.

Jansen-Verbeke, M., and J. van Rekom. 1996. “Scanning Museum Visitors.” Annals of Tourism Research 23 (2): $364-375$. doi:10.1016/0160-7383(95)00076-3.

60 Jewell, B., and J. C. Crotts. 2009. "Adding Psychological Value to Heritage Tourism Experiences Revisited." Journal of Travel and Tourism Marketing 26 (3): 244-263. doi:10.1080/10548400902925122. 
Johns, N. 1999. “Quality.” In Heritage Visitor Attractions: An Operations Management Perspective, edited by A. Leask and I. Yeoman, 127-143. London: Cassell.

Kerstetter, D., J. Confer, and K. Bricker. 1998. “Industrial Heritage Attractions: Types and Tourists.” Journal of Travel and Tourism Marketing 7 (2): 91-104. doi:10.1300/J073v07n02_05.

Kerstetter, D. L., J. J. Confer, and A. R. Graefe. 2001. "An Exploration of the Specialization Concept within the Context of Heritage Tourism.” Journal of Travel Research 39 (3): 267-274. doi:10.1177/004728750103900304.

Kotler, P. 1974. “Atmospherics as a Marketing Tool." Journal of Retailing 49 (4): 48-64.

Kottasz, R. 2006. "Understanding the Influences of Atmospheric Cues on the Emotional Responses and Behaviours of Museum Visitors." Journal of Nonprofit and Public Sector Marketing 16 (1-2): 95-121. doi:10.1300/J054v16n01_06.

Laws, E. 2001. “The Analysis of Quality for Heritage Site Visitors.” In Quality Issues in Heritage Visitor Attractions, edited by I. Yeoman and S. Drummond, 61-77. Oxford: Butterworth-Heinemann.

Leask, A., A. Fyall, and P. Barron. 2013a. “Generation Y: An Agenda for Future Visitor Attraction Research.” International Journal of Tourism Research, 16 (5): 462-471. doi:10.1002/jtr.1940.

Leask, A., A. Fyall, and P. Barron. 2013b. "Generation Y: Opportunity or Challenge - Strategies to Engage Generation Y in the UK Attractions' Sector." Current Issues in Tourism 16 (1): 17-46. doi:10.1080/13683500.2011.642856.

Leighton, D. 2007. “Step Back in Time and Live the Legend': Experiential Marketing and the Heritage Sector" International Journal of Nonprofit and Voluntary Sector Marketing 12 (2): 117-125. doi:10.1002/nvsm.288.

Marty, P. F. 2007. "Museum Websites and Museum Visitors: Before and after the Museum Visit." Museum Management and Curatorship 22 (4): 337-360. doi:10.1080/09647770701757708.

McCain, G., and N. M. Ray. 2003. “Legacy Tourism: The Search for Personal Meaning in Heritage Travel.” Tourism Management 24 (6): 713-717. doi:10.1016/S0261-5177(03)00048-7.

McIntosh, A. J. 1999. "Into the Tourist's Mind: Understanding the Value of the Heritage Experience." Journal of Travel and Tourism Marketing 8 (1): 41-64. doi:10.1300/J073v08n01_03.

McKercher, B., and H. du Cros. 2003. “Testing a Cultural Tourism Typology” International Journal of Tourism Research 5 (1): 45-58. doi:10.1002/jtr.417.

Mintel. 2010. Heritage Tourism - Ireland - December 2010.

Moreno Gil, S., and J. R. B. Ritchie. 2009. "Understanding the Museum Image Formation Process: A Comparison of Residents and Tourists." Journal of Travel Research 47 (4): 480-493. doi:10.1177/0047287508326510.

Moscardo, G. 1996. “Mindful Visitors.” Annals of Tourism Research 23 (2): 376-397. doi:10.1016/0160-7383(95)00068-2.

Mundfrom, D. J., D. G. Shaw, and T. L. Ke. 2005. "Minimum Sample Size Recommendations for Conducting Factor Analyses." International Journal of Testing 5 (2): 159-168. doi:10.1207/s15327574ijt0502_4.

Neuhofer, B., D. Buhalis, and A. Ladkin. 2013. "Experiences, Co-creation and Technology: A Conceptual Approach to Enhance Tourism Experiences." CAUTHE 2013: Tourism and Global Change: On the Edge of Something Big. Christchurch, New Zealand.

Nowacki, M. M. 2009. "Quality of Visitor Attractions, Satisfaction, Benefits and Behavioural Intentions of Visitors: Verification of a Model." International Journal of Tourism Research 11 (3): 297-309. doi:10.1002/jtr.689.

OECD. 2009. The Impact of Culture on Tourism. Paris: OECD Publishing.

OECD. 2012. OECD Tourism Trends and Policies 2012. Paris: OECD Publishing.

Oh, H., A. M. Fiore, and M. Jeoung. 2007. "Measuring Experience Economy Concepts: Tourism Applications." Journal of Travel Research 46 (2): 119-132. doi:10.1177/0047287507304039.

Packer, J., and R. Ballantyne. 2002. "Motivational Factors and the Visitor Experience: A Comparison of Three Sites." Curator: The Museum Journal 45 (3): 183-198. doi:10.1111/j.2151-6952.2002.tb00055.x.

Page, S. J. 2011. Tourism Management. 4th ed. London: Butterworth-Heinemann.

Palmer, C. 1999. "Tourism and the Symbols of Identity." Tourism Management 20 (3): 313-321. doi:10.1016/S02615177(98)00120-4.

Park, H. 2014. Heritage Tourism. London: Routledge.

Patterson, D., and Bitgood, S. 1988. Some Evolving Principles of Visitor Behaviour in Visitor Studies: Theory, Research and Practice, edited by S. Bitgood, J. T. Roper, Jr., and A. Benefield, 41-50. Jacksonville, FL: Center for Social Design.

Pearson, R. H., and D. J. Mundform. 2010. "Recommended Sample Size for Conducting Exploratory Factor Analysis on Dichotomous Data." Journal of Modern Applied Statistical Methods 9 (2): 359-368.

Petrelli, D., L. Ciolfi, D. van Dijk, E. Hornecker, E. Not, and A. Schmidt. 2013. "Integrating Material and Digital." Interactions 20 (4): 58-63. doi:10.1145/2486227.2486239.

Pine, B. J., and J. H. Gilmore. 1999. The Experience Economy: Work is Theatre and Every Business a Stage. Boston, MA: Harvard Business School Press.

Poria, Y., R. Butler, and D. Airey. 2003. “The Core of Heritage Tourism.” Annals of Tourism Research 30 (1): $238-254$. doi:10.1016/S0160-7383(02)00064-6.

Poria, Y., R. Butler, and D. Airey. 2004. "Links Between Tourists, Heritage, and Reasons for Visiting Heritage Sites." Journal of Travel Research 43 (1): 19-28. doi:10.1177/0047287504265508.

Prahalad, C. K., and V. Ramaswamy. 2004a. “Co-creating Unique Value with Customers." Strategy and Leadership 32 (3): 4-9. 
Prahalad, C. K., and V. Ramaswamy. 2004b. "Co-creation Experiences: The Next Practice in Value Creation." Journal of Interactive Marketing 18 (3): 5-14.

Prentice, R. 1993. "Motivations of the Heritage Consumer in the Leisure Market: An Application of the Manning-Haas Demand Hierarchy." Leisure Sciences 15 (4): 273-290.

Prentice, R., S. Guerin, and S. McGugan. 1998. "Visitor Learning at a Heritage Attraction: A Case Study of Discovery as a Media Product.” Tourism Management 19 (1): 5-23. doi:10.1016/S0261-5177(97)00077-0.

Pyo, S. 2005. "Knowledge Map for Tourist Destinations - Needs and Implications." Tourism Management 26 (4): 583-594. doi:10.1016/j.tourman.2004.03.001.

Rashid, B. 2013. "Post Visit Assessment: The Influence of Consumption Emotion on Tourist Future Intention." Journal of Business and Management 9 (3): 39-45.

Richards, G. 2001a. Cultural Attractions and European Tourism. Wallingford: CABI.

Richards, G. 2001b. "The Experience Industry and the Creation of Attractions." In Cultural Attractions and European Tourism, edited by G. Richards, 55-69. Oxfordshire, UK: CABI Publishing.

Richards, G. 2012. "An Overview of Food and Tourism Trends and Policies." OECD Food and the Tourism Experience: The OECD-Korea Workshop, OECD Studies on Tourism, 13-46. Paris: OECD Publishing.

Richards, G., and J. Wilson. 2006. "Developing Creativity in Tourist Experiences: A Solution to the Serial Reproduction of Culture?” Tourism Management 27 (6): 1209-1223. doi:10.1016/j.tourman.2005.06.002.

de Rojas, C., and C. Camarero. 2008. "Visitors' Experience, Mood and Satisfaction in a Heritage Context: Evidence from an Interpretation Center." Tourism Management 29 (3): 525-537. doi:10.1016/j.tourman.2007.06.004.

Rowley, J. 1999. "Measuring Total Customer Experience in Museums." International Journal of Contemporary Hospitality Management 11 (6): 303-308. doi:10.1108/09596119910281801.

Schouten, F. 1995. "Improving Visitor Care in Heritage Attractions." Tourism Management 16 (4): 259-261. doi:10.1016/0261-517795)00014-F.

Sharifi-Tehrani, M., M. Verbič, and J. Y. Chung. 2013. "An Analysis of Adopting Dual Pricing for Museums." Annals of Tourism Research 43: 58-80. doi:10.1016/j.annals.2013.04.001.

Shore, S. 2010. Cultural and Heritage Tourism - International - May 2010. London: Mintel.

Stamboulis, Y., and P. Skayannis. 2003. "Innovation Strategies and Technology for Experience-based Tourism.” Tourism Management 24 (1): 35-43. doi:10.1016/S0261-5177(02)00047-X.

Swarbrooke, J., and S. Horner. 2007. Consumer Behaviour in Tourism. 3rd ed. Oxford: Butterworth-Heinemann.

Tchetchik, A., A. Fleischer, and N. Shoval. 2009. "Segmentation of Visitors to a Heritage Site Using High-resolution Time-space Data." Journal of Travel Research 48 (2): 216-229. doi:10.1177/0047287509332307.

Timothy, D. J. 1997. "Tourism and the personal heritage experience." Annals of Tourism Research 24 (3): 751-754.

Timothy, D. J. 2011. Cultural Heritage and Tourism: An Introduction. Bristol: Channel View Publications.

Timothy, D. J., and S. W. Boyd. 2003. Heritage Tourism. New York: Pearson Education.

Tussyadiah, I. P., and D. R. Fesenmaier. 2009. "Mediating Tourist Experiences." Annals of Tourism Research 36 (1): 24-40. UNWTO. 2010. World Tourism Barometer January 2010. UNWTO.

Wakefield, K. L., and J. G. Blodgett. 1994. "The Importance of Servicescapes in Leisure Service Settings." Journal of Services Marketing 8 (3): 66-76. doi:10.1108/08876049410065624.

Worthington, R. L., and T. A. Whittaker. 2006. "Scale Development Research: A Content Analysis and Recommendations for Best Practices." The Counseling Psychologist 34 (6): 806-838. doi:10.1177/0011000006288127.

Wu, Mao-Ying, and G. Wall. 2016. "Visiting Heritage Museums with Children: Chinese Parents' Motivations." Journal of Heritage Tourism 12 (1): 1-16. doi:10.1080/1743873X.2016.1201085.

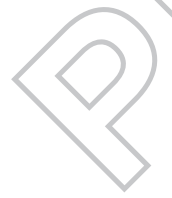

